\title{
TREN KEBUTUHAN KUALIFIKASI JURNALIS RADIO PADA INDUSTRI RADIO SIARAN DI KOTA BANDUNG
}

\author{
Pandan Yudhapramesti, Efi Fadilah \\ Departemen Ilmu Jurnalistik, Fakultas Ilmu Komunikasi Universitas Padjadjaran
}

\begin{abstract}
ABSTRAK
Untuk mengetahui kualifikasi sumber daya manusia yang dibutuhkan dunia kerja, perguruan tinggi seyogyanya aktif melakukan pendekatan serta penelitian terhadap dunia kerja. Penelitian ini diarahkan untuk mengetahui serta merumuskan kualifikasi sumber daya manusia di bidang jurnalistik radio yang dibutuhkan oleh radio siaran dalam aspek pemahaman terhadap filosofi jurnalistik, karakter media, kemampuan mengolah pesan untuk siaran radio, serta pemahaman etika profesi.Penelitian dilakukan terhadap tiga stasiun radio siaran di Bandung yaitu Radio PR FM, Radio Republik Indonesia, dan Radio Litasari FM. Penelitian menggunakan metode deskriptif kualitatif dimana data diperoleh melalui pengamatan dan wawancara mendalam. Hasil penelitian menunjukkan bahwajurnalis radio yang dibutuhkan adalahyang memahami filosofi perannya sebagai pembawa pesan serta memahami karakteristik radio siaran agar optimal mengolah pesan untuk radio. Mereka juga diharapkan dapat menjunjung tinggi etika profesi. Sejalan dengan perkembangan teknologi berbasis internet, para jurnalis radio juga dituntut bekerja dalam pola kerja media konvergensi. Pengelola radio menyadari kesenjangan antara kondisi ideal dan real kualifikasi jurnalis radio,namun mengaku kesulitan mengatasinya. Kondisi ini menjadi tantangan sekaligus peluang bagi perguruan tinggi untuk menyediakan calon jurnalis radio dengan kualifikasi yang memadai.
\end{abstract}

Kata-kata kunci: Radio siaran, kualifikasi jurnalis, pesan radio, konvergensi media

\section{TRENDS OF RADIO JOURNALISTS QUALIFICATION REQUIREMENTS IN BROAD- CAST RADIO INDUSTRY IN BANDUNG}

\begin{abstract}
Higher education institution should actively monitoring the manpower qualification needed by workplace through conducting research on the particular problem. This study aims to determine the qualification of human resources in the field of radio journalism required by radio broadcast industry from the aspect of understanding the philosophy of journalism, the character of radio broadcasts, the ability to process messages for radio, as well as the understanding of professional ethics. This studyis conducted in three radio stations in Bandung namely, Radio PR FM, Radio Republik Indonesia, and Radio Litasari FM. This study uses descriptive qualitative method in which the data is obtained through observation and in-depth interviews. The results show that the industry demands journaliststo have a comprehensive undestanding of the philosophy at his role as a messenger as well asan understanding of media characteristic in order tohave an optimum radio messages. They are also expected to uphold their professional ethics. In line with the development of internet-based technology, they are also required to work in the media convergence setting. This study found a gap between the ideal and the real conditions on the qualifications of radio journalists. The radio managers are aware of these circumstances, however they admit having it difficult to deal with it. This condition can be both a challenge and an opportunity for universities in preparing eligible radio journalist candidates.
\end{abstract}

Keywords: Radio broadcast, journalist qualification, messages for radio, media convergence

Korespondensi: Pandan Yudhapramesti, S.Sos, M.Si, Departemen Ilmu Jurnalistik, Fakultas Ilmu Komunikasi Universitas Padjadjaran, Jl.Raya Bandung-Sumedang Km.21, Email: pandanpramesti@gmail.com 


\section{PENDAHULUAN}

Media massa merupakan bagian penting dalam kehidupan masyarakat dunia dewasa ini. Kenyataan ini menunjukkan bahwa kualitas sumber daya manusia (SDM) pengelola media massa merupakan titik krusial yang akan menentukan kualitas isi media. Pada gilirannya, kualitas isi media massa akan memengaruhi kualitas masyarakat yang mengakses media tersebut. Karenanya, kualifikasi SDM yang dibutuhkan oleh pengelola media harus disadari dengan baik oleh pihak-pihak yang berkepentingan, seperti pengelola media itu sendiri, serta perguruan tinggi khususnya jurusan maupun fakultas yang secara khusus menyiapkan SDM yang akan mengisi posisi-posisi di bidang pengelolaan media.

Seperti kita ketahui bersama, terdapat berbagai jenis media massa, dari yang menggunakan teknologi sederhana seperti media massa cetak sederhana, hingga menggunakan teknologi canggih seperti internet. Dari kaca mata teknologi media, teknologi radio siaran memang terbilang ketinggalan. Namun hingga hari ini, radio masih didengarkan cukup banyak orang. Berdasarkan data Nielsen Media Reseach ${ }^{1}$, radio dengan raihan khalayak tertinggi di Kota Bandung, masih didengarkan oleh lebih dari 400 ribu orang. Sebagai gambaran tambahan, radio dengan peringkat ke 10 masih didengarkan oleh lebih dari 100 ribu orang. Angka ini belum termasuk khalayak yang beralih mengakses siaran radio yang telah beradaptasi dengan teknologi internet berupa streaming siaran radio serta podcast yang juga dikenal dengan istilah On Demand Interactive Radio (ODIR).

Sejak lama radio siaran dikenal sebagai media dari rakyat untuk rakyat. Berbeda dengan televisi (TVRI) yang pernah digunakan sebagai sarana propaganda pemerintah zaman orde baru, atau televisi nasional yang lebih banyak memompakan isu nasional yang belum tentu dibutuhkan masyarakat daerah. Sepanjang sejarahnya di Indonesia, radio telah menjadi bagian dari dinamika rakyat. Siaran radio yang berisi hiburan rakyat dan informasi lokal telah menjadi cermin dari dinamika masyarakat daerah.

Seiring dengan berbagai usaha dan stra gi

1 Hasil survey NMR triwulan ke tiga tahun 2008 yang dilancarkan, sejak dulu media radio dikenal sebagai media yang punya kekuatan menajamkan khalayaknya. Pilihan radio siaran untuk memasukkan elemen informasi, baik dalam bentuk berita, talkshow, feature atau bentuk-bentuk jurnalisme radio yang lain, sebenarnya mengembalikan fungsi radio tidak hanya sekedar menjadi medium hiburan akan tetapi juga berfungsi sebagai medium informasi dan edukasi. Pilihan ini juga yang kemudian membuat stasiun radio membutuhkan tenaga-tenaga handal untuk menangani siaran informasinya dalam berbagai bentuk tersebut. Kenyataannya, masih banyak pengelola radio siaran yang mengeluhkan minimnya kualitas sumber daya manusia di bidang jurnalistik radio.

Dilihat dari aspek perkembangan jurnalisme, terasa sekali bahwa jurnalisme radio di Indonesia berjalan di tempat, nyaris tak ada terobosan dalam kreasi, dan semua hanya menghadirkan rutinitas demi rutinitas (Fadilah, 2007). Seorang tokoh pendidik jurnalis radio, Eric Sasono mengkhawatirkan terjadi proses menghilangnya "quality jurnalism" pada dunia radio (Sasono, 2005). Saat ini, setelah lebih dari lima tahun berlalu fakta memprihatinkan ini masih terus terjadi bahkan semakin memprihatinkan.

Tidak heran bila kenyataan di atas membuat sebagian pihak mempertanyakan kontribusi institusi pendidikan tinggi yang menghasilkan para calon jurnalis, khususnya radio. Sebenarnya hal ini telah ditenggarai oleh Thomas Hanitzsch, seorang kandidat doktor dari Universitas Ilmenau, Jerman, pada awal tahun 2000-an. Meski Hanitzsh menyoroti pendidikan bagi jurnalis di Indonesia secara umum, namun hasil penelitiannya dapat juga dijadikan gambaran untuk bidang jurnalistik radio.

Dalam riset awalnya, "Rethinking Journalism Education in Indonesia: Nine Theses, ”yang diterbitkan jurnal Mediator terbitan Universitas Islam Bandung, Hanitzch (2001) mengedepankan beberapa kesimpulan. Pertama, pendidikan jurnalisme di Indonesia masih dihambat oleh apa yang disebut sebagai "kurikulum nasional." Kedua, tak ada interaksi antara pendidikan jurnalisme dan industri media. Sekolah jurnalisme punya dunianya sendiri, sedangkan industri media berada pada dunia yang lain. Ketiga, semua sekolah ini tak dilengkapi dengan teknologi yang memadai. Keempat, di Indonesia, ada 69 
sekolah jurnalisme (dari D-1 hingga S-3) tapi 80 persen ada di Pulau Jawa dan Medan. Daerah Timur, dari Makassar hingga Jayapura, dari Maluku hingga Kupang, adalah daerah-daerah yang tak punya sekolah jurnalisme.

Riset Hanisztch (2001) juga mencatat bahwa ke 69 sekolah jurnalisme di masa penelitiannya memiliki 19 ribu mahasiswa. Kenyataannya di lapangan, para redaktur media massa sering mengeluh kesulitan mencari tenaga wartawan atau paling tidak orang yang akan dididik menjadi wartawan. Padahal bila dilihat dari jumlah, sekolah-sekolah jurnalisme tadi dapat memasok lebih dari cukup sumber daya manusia yang dibutuhkan.

Berdasarkan paparan sebelumnya pada bagian Pendahuluan, maka penulis merumuskan permasalahan "Apa kualifikasi jurnalis yang dibutuhkan industri radio siaran di Kota Bandung berkaitan dengan aspek pemahaman filosofis profesi dan karakteristik media, kemampuan mengolah pesan untuk media radio siaran, serta pemahaman akan etika profesi sebagai jurnalis radio?"

Berdasarkan rumusan masalah di atas maka tujuan penelitian adalah sebagai berikut: (1). Untuk mengetahui dan merumuskan kebutuhan industri radio siaran akan kualifikasi jurnalis dalam aspek pemahaman terhadap filosofi jurnalistik; (2). Untuk mengetahui dan merumuskan kebutuhan industri radio siaran akan kualifikasi jurnalis dalam aspek pemahaman terhadap karakter media; (3). Untuk mengetahui dan merumuskan kebutuhan industri radio siaran akan kualifikasi jurnalis dalam aspek kemampuan dalam mengolah pesan untuk siaran radio; dan (4). Untuk mengetahui dan merumuskan kebutuhan industri radio siaran akan kualifikasi jurnalis dalam aspek pemahaman etika profesi.

Penelitian terhadap industri radio siaran termasuk jarang dilakukan di Indonesia, dibandingkan dengan penelitian terhadap media massa lain seperti media cetak baik surat kabar, majalah, maupun tabloid, serta media elektronik televisi. Namun demikian, terdapat beberapa penelitian baru mengenai radio siaran, seperti yang telah dilakukan Efi Fadilah (2007) dalam Pemanfaatan Media Audio menggunakan Model Assure, serta Pandan Yudhapramesti (2009) dalam Muatan Lokal pada Siaran Radio: Peran Radio Siaran sebagai Media Lokal dalam Pem- bangunan Daerah. Kedua penelitian tersebut antara lain mengungkapkan keprihatinan terhadap menurunnya kualitas siaran radio terutama pada siaran informasi/jurnalistik di Indonesia. Penurunan ini terjadi karena berbagai aspek internal dalam radio siaran maupun eksternal di luar radio siaran.

Setidaknya terdapat dua faktor agar media massa dapat menjalankan fungsinya secara optimal. Faktor pertama adalah faktor eksternal, yaitu terciptanya iklim sosial, politik, serta ekonomi yang sehat agar media massa dapat beroperasi secara profesional. Pengelola media massa, khususnya pers, harus memperoleh kebebasan yang memadai agar dapat menjalankan fungsinya sebagai jendela informasi dan kontrol sosial. Media juga harus sehat secara bisnis agar dapat beroperasi secara berkesinambungan. Agar dapat sehat secara bisnis, faktor ekonomi secara luas atau makro turut memengaruhi keberlangsungan operasional bisnis media massa.

Faktor kedua adalah faktor internal, yaitu media massa memiliki syarat-syarat yang seyogyanya dimiliki oleh sebuah organisasi untuk tumbuh sehat. Sebagai sebuah organisasi, media massa harus memiliki sumber daya yang memadai, baik sumber daya permodalan, teknologi, maupun sumber daya manusia berkualitas, yaitu sumber daya manusia yang memiliki kecakapan memadai untuk bekerja dalam sebuah organisasi media massa. Pada kondisi ideal seperti itulah media massa dapat optimal menjalankan peran dan fungsinya.

Jurnalistik radio terdiri dari dua kata, jurnalistik dan radio. Jurnalistik berasal dari istilah bahasa Inggris, journalism. Kata dasarnya "journal" berasal dari Bahasa Latin Kuno, "diurnal", artinya laporan atau catatan harian. Onong Uchjana Effendi menyimpulkan pengertian jurnalistik sebagai catatan harian dengan segala aspeknya, mulai dari mencari, mengolah, sampai kepada menyebarluaskan catatan tersebut (Effendi, 1990). Secara harfiah jurnalistik juga diartikan sebagai kewartawanan.Adapun istilah radio mengacu pada salah satu jenis media penyiaran. Radio unggul dalam kecepatan dan sederhana. Karakteristik inilah yang membuat medium ini sangat diandalkan untuk menyampaikan breaking news (Gibson, 1991). Jurnalistik radio pada umumnya meliputi warta berita, editorial udara, wawancara udara, feature uda- 
ra, news round ups, dan newsreel, serta reportage on the scene.

Asep Syamsul M. Romli (2005) mengatakan bahwa secara konseptual, jurnalistik dapat dipahami dari tiga sudut pandang: sebagai proses, teknik, dan ilmu. Sebagai proses, jurnalistik meliputi aktivitas mencari, mengolah, menulis, dan menyebarluaskan informasi kepada publik melalui media massa. Aktivitas ini dilakukan oleh seorang jurnalis. Sebagai teknik, jurnalistik adalah keahlian (expertise) atau keterampilan (skill) menulis karya jurnalistik termasuk keahlian dalam mengumpulkan bahan penelitian seperti peliputan peristiwa dan wawancara. Sebagai ilmu, jurnalistik adalah bidang kajian mengenai pembuatan dan penyebarluasan informasi (peristiwa, opini, pemikiran, ide) melalui media massa. Jurnalistik termasuk ilmu terapan (applied science) yang dinamis dan terus berkembang sesuai dengan perkembangan teknologi informasi dan komunikasi dan dinamika masyarakat.

Sudut pandang di atas diterjemahkan menjadi tuntutan keahlian yang harus dimiliki oleh seorang jurnalis radio.Tentunya selain memiliki keahlian jurnalistik dasar, seorang jurnalis radio harus dapat menyesuaikan atau mengaplikasikan keahlian atau keterampilan jurnalistik dasar tersebut pada media radio yang memiliki karakteristik tersendiri. Jonathans (2006) menguraikan bahwa seorang jurnalis radio memang dituntut memiliki multi keahlian meliputi keahlian dalam perencanaan, keahlian dalam penggalian informasi, keahlian dalam penelitian, keahlian dalam pengendalian perangkat produksi, keahlian dalam penyiaran atau presentasi berita, dan keahlian dalam melakukan evaluasi.

Jurnalis radio harus mampu merencanakan peliputan dan penyiaran informasi. Pekerjaan ini tidak semata dibebankan kepada redaksi tentunya tanpa mengabaikan fungsi birokrasi pemberitaan di radio. Dengan kemampuan ini pekerjaan di redaksi dan newsroom dapat dipercepat.

Penggalian informasi merupakan gerbang awal memperoleh data dan fakta. Runtutan kerja sebelum terjun ke lapangan adalah menyelusuri data melalui penggalian arsip, dokumentasi, kepustakaan, narasumber, termasuk akses internet yang berujud rekaman audio maupun visual. Wawancara termasuk salah satu pendekatan untuk menggali data, disamping observasi ke lapangan.

Proses kegiatan intelektual reporter adalah menulis seluruh hasil liputannya, kecuali peliputan itu disiarkan secara langsung dalam bentuk live reportage. Tetapi untuk kemasan jurnalistik radio lainnya, penelitian adalah jembatan reporter untuk menghubungkan proses peliputan dengan penyiaran. Kemampuan penelitiannya dianggap berhasil apabila reporter mampu menghasilkan "penelitian bertutur". Yaitu konsep penelitian yang bermuara pada kebutuhan telinga khalayak, bukan pada kebutuhan mata pendengar untuk membaca informasi.

Jurnalis radio harus menguasai teknik merekan, editing, juga program komputer, digital dan satelit dalam teknologi komunikasi menjadi perangkat yang harus menyatu dengan kegiatan reporter. Seiring perkembangan teknologi, jurnalis radio juga harus mampu beradaptasi untuk dapat bekerja dalam pola kerja media baru atau media konvergensi yang berbasis internet.

Keparipurnaan keterampilan seorang jurnalis radio juga diukur dari kemampuannya bersiaran atau menyampaikan sendiri hasil liputannya. Penyampaian informasi dalam konteks pemahaman makna, suasana, dan akurasi visualisasinya dapat tercapai apabila reporter sendiri yang menyiarkannya.

Untuk mengukur kualitas informasi dan pemberitaan, seorang reporter harus mampu melakukan evaluasi mandiri terhadap karya liputan dan penyiarannya. Biasanya evaluasi dilakukan redaksi dan bidang penyiaran, tetapi bila reporter mampu mengevaluasi penyiaran informasinya dengan mencermati reaksi dan respon khalayak pendengar, maka ia dapat meningkatkan kualitas pemberitaannya dengan mudah dan cepat. Secara profesional ia dapat meminta tanggapan langsung dari pendengar, tim kerjanya atau ahli. Hanya saja dalam kenyataan sehari-hari, reporter radio jarang melakukan evaluasi secara mandiri.

Selain keahlian-keahlian seperti tersebut di atas, jurnalis radio juga harus mengerti ketentuan perundang-undangan dan turunannya yang berkaitan dengan profesinya. Dalam praktik penegakan kebebasan pers di negeri ini, pekerjaan jurnalis dilindungi oleh sejumlah peraturan perundang-undangan serta turunannya, termasuk kode etik. Kode etik menjadi pedoman 
perilaku para jurnalis dalam melaksanakan aktivitasnya. Pedoman perilaku mengatur hal yang boleh dan tidak boleh dilakukan jurnalis. Di dalam kode etik Jurnalistik yang disusun oleh berbagai organisasi profesi Wartawan Indonesia serta difasilitasi oleh Dewan Pers dinyatakan bahwa untuk menjamin kemerdekaan pers dan memenuhi hak publik untuk memperoleh informasi yang benar, wartawan Indonesia memerlukan landasan moral dan etika profesi sebagai pedoman operasional dalam menjaga kepercayaan publik dan menegakkan integritas serta profesionalisme.

Untuk menjaga keprofesionalan seorang wartawan saat melaksanakan tugasnya, Dewan Pers juga menyusun Standar Kompetensi Wartawan (SKW) Indonesia. Standar kompetensi wartawan diperlukan untuk melindungi kepentingan publik dan hak pribadi masyarakat. Standar ini disusun untuk menjaga kehormatan pekerjaan wartawan dan bukan untuk membatasi hak asasi warga negara menjadi wartawan.

Kompetensi wartawan pertama-pertama berkaitan dengan kemampuan intelektual dan pengetahuan umum. Di dalam kompetensi wartawan melekat pemahaman tentang pentingnya kemerdekaan berkomunikasi, berbangsa, dan bernegara yang demokratis. Kompetensi wartawan meliputi kemampuan memahami etika dan hukum pers, konsepsi berita, penyusunan dan penyuntingan berita, serta bahasa. Dalam hal yang terakhir ini juga menyangkut kemahiran melakukannya, seperti juga kemampuan yang bersifat teknis sebagai wartawan profesional, yaitu mencari, memperoleh, menyimpan, memiliki, mengolah, sertamembuat dan menyiarkan berita.

Di dalam SKW juga terdapat panduan mengenai elemen unjuk kerja wartawan, yaitu bentuk pernyataan yang menggambarkan proses kerja pada setiap elemen kompetensi. Elemen kompetensi disertai dengan kriteria unjuk kerja harus mencerminkan aktivitas aspek pengetahuan, keterampilan, dan sikap kerja. Di dalamnya juga terdapat elemen kompetensi berdasarkan strata pengalaman wartawan, yaitu elemen kompetensi wartawan muda, wartawan madya, serta wartawan utama. Untuk kategori wartawan muda, elemen kompetensinya adalah: (1). Mengusulkan dan merencanakan liputan; (2). Menerima dan melaksanakan penugasan;
(3). Mencari bahan liputan, termasuk informasi dan referensi; (4). Melaksanakan wawancara; (5). Mengolah hasil liputan dan menghasilkan karya jurnalistik; (6). Mendokumentasikan hasil liputan dan membangun basis data pribadi; dan (7). Membangun dan memelihara jejaring dan lobi.

Untuk kategori wartawan madya, elemen kompetensinya adalah: (1). Menyunting karya jurnalistik wartawan; (2). Mengompilasi bahan liputan menjadi karya jurnalistik; (3). Memublikasikan berita layak siar; (4). Memanfaatkan sarana kerja berteknologi informasi; (5). Merencanakan, mengoordinasikan dan melakukan liputan berkedalaman (indepth reporting); (6). Merencanakan, mengoordinasikan dan melakukan liputan investigasi (investigative reporting); (7). Menyusun peta berita untuk mengarahkan kebijakan redaksi di bidangnya; (8). Melakukan evaluasi pemberitaan dibidangnya; (9). Membangun dan memelihara jejaring dan lobi; dan (10). Memiliki jiwa kepemimpinan.

Sedangkan untuk kategori wartawan utama, elemen kompetensinya adalah: (1). Menyunting karya jurnalistik wartawan; (2). Mengompilasi bahan liputan menjadi karya jurnalistik; (3). Memublikasikan berita layak siar; (4). Memanfaatkan sarana kerja berteknologi informasi; (5). Merencanakan, mengoordinasikan dan melakukan liputan berkedalaman (indepth reporting); (6). Merencanakan, mengoordinasikan dan melakukan liputan investigasi (investigative reporting); (7). Menyusun peta berita untuk mengarahkan kebijakan redaksi; (8). Melakukan evaluasi pemberitaan; (9). Memiliki kemahiran manajerial redaksi; (10). Mengevaluasi seluruh kegiatan pemberitaan; (11). Membangun dan memelihara jejaring dan lobi; (12). Berpandangan jauh ke depan/visioner; (13). Memiliki jiwa kepemimpinan.

Melalui elemen kompetensi ini, tergambar dengan jelas secara konseptual, kompetensi apa saja yang harus dimiliki oleh seorang jurnalis. Namun demikian, elemen kompetensi ini masih sangat umum, belum memperhitungkan karakter media massa. Karenanya, untuk kepentingan penelitian ini, elemen kompetensi yang dipersyaratkan oleh Dewan Pers seyogyanya dikaitkan dengan konsep-konsep yang berkenaan dengan karakter radio siaran, seperti telah diuraikan dalam halaman terdahulu, sehing- 
ga tergambar dengan jelas, secara konseptual, standar kompetensi apa yang perlu dimiliki oleh seorang wartawan radio.

Radio siaran adalah media elektronik yang hanya menghasilkan produk suara. Karena produknya hanya suara maka radio siaran memiliki karakteristik selintas, cepat, mengundang imajinasi pendengarnya, serta dapat dinikmati sambil melakukan hal lain (secondary medium). Secara teknologi, radio siaran merupakan media yang sederhana, mudah dan murah dioperasikan. Karakteristik ini merupakan keunggulan sekaligus kelemahan radio siaran. Sifatnya yang secondary medium membuat radio siaran dapat mendekatkan diri pada khalayaknya kapan pun, di mana pun, dalam berbagai situasi. Namun sifatnya yang selintas dapat membuat pendengar salah mengerti. Diperlukan pemahaman akan karakteristik medium suara agar seorang jurnalis radio dapat mengolah pesan suara yang berkualitas, mudah dimengerti serta menarik.

Penelitian ini diharapkan dapat memberi kontribusi kepada pihak-pihak yang berkecimpung dalam bidang jurnalistik radio dalam hal; (1). Bagi perguruan tinggi, khususnya jurusan atau fakultas yang bergerak dalam pendidikan jurnalistik atau pengelolaan media, penelitian ini dapat memberi sumbangan informasi mutakhir tentang kondisi industri radio serta identifikasi yang lebih jelas tentang kualifikasi SDM yang dibutuhkan industri radio siaran; dan (2). Bagi pengelola radio siaran, penelitian diharapkan dapat menjadi rujukan/referensi tentang kualifikasi ideal seorang jurnalis radio.

Pada gilirannya, identifikasi tentang kualifikasi SDM di bidang jurnalistik radio yang dipahami bersama oleh pihak-pihak yang berkecimpung dalam bidang jurnalistik radio merupakan sumbangan untuk meningkatkan kualitas media radio siaran.

\section{METODE PENELITIAN}

Sejalan dengan tujuan penelitian, penulis menggunakan metode penelitian kualitatif dengan tipe deskriptif. Menurut Moleong, penelitian kualitatif bermaksud untuk memahami fenomena tentang pengalaman subjek penelitian yang termanifestasi dalam perilaku, persepsi, motivasi, tindakan dan lain sebagainya (Moleong,
2006: 6). Usaha memahami subjek penelitian ini, yaitu tiga stasiun radio siaran di Kota Bandung, dilakukan dalam latar alamiah mengingat pemahaman utuh hanya bisa didapat dari entitas yang juga utuh dan tidak terpisah dari konteksnya (Lincoln dan Guba dalam Moleong, 2006: 8). Kumpulan fenomena tersebut kemudian dideskripsikan secara sistematis, faktual, dan akurat (Kriyantono, 2010: 69). Dalam penelitian deskriptif kualitatif, peneliti berperan sebagai fasilitator dan secara kritis memaknairealitas dari subjek penelitian (Kriyantono, 2010: 389).

Kegiatan penelitian berjalan melalui beberapa tahapan mulai dari pra penelitian sampai tahap terakhir berupa penarikan kesimpulan dan pelaporan hasil penelitian. Peneliti melakukan modifikasi dari tahapan penelitian yang disusun oleh Bogdan dimana penelitian kualitatif terdiri dari (1) tahap pra lapangan, (2) kegiatan lapangan, dan terakhir (3) tahap analisis intensif. Uraian rinci mengenai aktivitas (termasuk teknik) pengumpulan data penelitian dapat mengambarkan modifikasi tahapan yang dimaksud, yaitu:

Pra riset dan pra lapangan yang bertujuan untuk mengetahui karakteristik program siaran jurnalistik radio di Kota Bandung termasuk mengetahui kelemahan dan kekuatannya. Dilakukan melalui pengamatan terhadap seluruh program siaran jurnalistik radio di Kota Bandungyang diproduksi sendiri oleh radio siaran bersangkutan. Kota Bandung dipilih dengan pertimbangan karena Kota Bandung merupakan kota di Indonesia yang memiliki jumlah stasiun radio paling banyak berdasarkan rasio jumlah penduduknya. Data ini menunjukkan bahwa industri radio siaran di Kota Bandung sangatlah hidup.

Penentuan fokus dan subjek penelitian melalui pengamatan terhadap program siaran jurnalistik, akan diketahui kelemahan-kelemahan program serta sumber yang menjadi penyebabnya. Berdasarkan temuan tingkat pertama, dipilih tiga radio siaran di Kota Bandung yang paling banyak menyiarkan program siaran jurnalistik, yaitu: (1). Radio PR FM, radio swasta dengan format siaran Jurnalisme Warga. Radio PR FM merupakan radio lokal Bandung dengan materi siaran jurnalistik hampir mencapai 100 persen. Kondisi ini membuat PR FM menjadi radio siaran dengan materi siaran jurnalistik paling banyak; (2). Radio Litasari FM, radio swasta dengan format 
siaran keluarga. Dengan format siaran keluarga, Radio Litasari FM memiliki acara siaran yang beranekaragam, termasuk beberapa program siaran jurnalistik yaitu siaran berita dan talkshow jurnalistik; dan (3). Radio Republik Indonesia programa 1 dan program 3.

Data yang diperoleh berdasarkan pengamatan terhadap acara siaran jurnalistik ini menjadi indikator kualitas jurnalis radio yang mengolah program siaran tersebut. Data tersebut akan diperkuat melalui tahap berikutnya.

Pengumpulan data lapangan dengan melakukan pengamatan terhadap proses pengolahan karya jurnalistik dari proses awal hingga akhir di tiga radio yang diamati. Pengamatan selanjutnya diarahkan pada sisi kelebihan dan kekurangan yang dimiliki oleh para jurnalis dari tiga radio yang dimiliki. Selanjutnya dilakukan wawancara mendalam terhadap penanggungjawab siaran jurnalistik radio dan jurnalis radio, dalam hal ini adalah wawancara dengan wakil pemimpin redaksi PR FM Basith Patria, pemimpin redaksi Lita FM Donny Prasetya, serta Kepala Bidang Siaran Radio Republik Indonesia cabang Bandung Sulaeman.

Data yang dikumpulkan melalui pengamatan serta wawancara kemudian diolah, disarikan, diklasifikasi agar dapat diperoleh gambaran yang rinci dan sistematis tentang kebutuhan industri radio siaran akan kualifikasi SDM Jurnalis. Temuan data akan diperkuat keabsahannya melalui triangulasi, melihat kesesuaian data antara berbagai sumber data, seperti melihat kesesuaian data antara hasil pengamatan dan hasil wawancara, atau membandingkan hasil wawancara dengan penanggungjawab siaran dan jurnalis radio. Permasalahan yang ditemukan di lapangan akan didekati dengan menggunakan teori serta konsep yang berkaitan dengan keterampilan di bidang jurnalistik, programming siaran radio, serta etika profesi. Pendekatan teoritis pada temuan data dari lapangan diharapkan dapat membantu mengarahkan penelitian ini pada kesimpulan yang komprehensif mengenai kualifikasi jurnalis radio yang dibutuhkan oleh industri radio siaran.

\section{HASIL DAN PEMBAHASAN}

Sesuai perencanaan penelitian, tahap pertama pengumpulan data dilakukan dengan mengama- ti program siaran seluruh radio siaran yang memancarluaskan siarannya di Kota Bandung. Berdasarkan pengamatan diketahui ada beberapa radio siaran yang menyiarkan karya jurnalistik radio diantaranya yaitu Radio PR FM, Radio Republik Indonesia, Radio Litasari FM, Radio Sindo, Radio Elshinta, Radio Delta, Radio Mara, Radio I, Radio Ardan dan beberapa stasiun radio lainnya. Namun dari sekian banyak radio tersebut, hanya sebagian radio yang memproduksi karya jurnalistik radio sendiri dan menyiarkannya, seperti radio PR FM, Radio Republik Indonesia, Radio Litasari FM, Radio Sindo, serta Radio Mara. Sedangkan radio-radio seperti Elshinta dan Radio I, meski menyiarkan program siaran jurnalistik, sebagian besar program siaran jurnalistiknya dipasok oleh perusahaan induk mereka yang berdomisili di Jakarta. Untuk kepentingan penelitian ini, dipilihlah tiga stasiun radio lokal Bandung yang paling banyak memproduksi dan menyiarkan program siaran jurnalistik hasil karya para reporter/jurnalisnya sendiri.

Berdasarkan pengamatan terhadap ketiga radio siaran, yaitu Radio PR FM, Radio Republik Indonesia, dan Radio Litasari, diketahui bahwa ketiga radio siaran memiliki jenis program siaran jurnalistik yang beraneka ragam, namun secara garis besar dapat dikelompokkan ke dalam jenis program berita, feature, siaran perbincangan atau talkshow serta majalah udara atau air magazine. Di antara ke empat bentuk karya jurnalistik tersebut, program siaran berita serta perbincangan merupakan jenis karya jurnalistik yang paling banyak diproduksi dan disiarkan.

Alasannya pada umumnya adalah karena berita dan talk show lebih mudah diproduksi dan disiarkan, dari pada feature dan majalah udara. Namun demikian apapun bentuk karya jurnalistik yang disiarkan, semuanya menuntut SDM jurnalis berkualifikasi baik agar dapat menghasilkan karya jurnalistik yang baik.

Pada praktiknya, pengelola ketiga radio siaran yang diteliti mengaku memiliki berbagai kesulitan menghasilkan karya jurnalistik yang berkualitas. Ada berbagai alasan yang melatari berbagai kesulitan tersebut. Salah satu penyebab utamanya adalah karena kesulitan memperoleh SDM jurnalis yang handal.

Kualitas sumber daya manusia tentu saja dipengaruhi oleh banyak hal. Dalam kaitannya 
dengan kompetensi profesi jurnalis radio siaran, kualitas jurnalis radio pada mulanya ditentukan sejak proses rekruitmen. Tabel di bawah ini menggambarkan kriteria yang ditetapkan pada tiga radio siaran yang diteliti saat proses rekruitmen dilakukan.

Tabel 1 menggambarkan kriteria yang ditetapkan oleh ketiga radio siaran saat merekrut kandidat jurnalis. Ketiganya bersedia menerima kandidat yang baru saja lulus sekolah atau fresh graduate, jika sedang tersedia posisi yang lowong. Pada dasarnya, aspek yang menjadi perhatian utama dari diri kandidat adalah pengetahuan umum yang cukup luas serta etos kerja yang baik karena profesi jurnalis membutuhkan ketangguhan untuk bekerja di lapangan. Latar belakang pendidikan jurnalistik diakui menjadi nilai tambah baik bagi kandidat jurnalis maupun radio siaran yang akan merekrut, namun tidak wajib. Setelah memperoleh penugasan sebagai jurnalis, secara bertahap kompetensinya sebagai jurnalis akan ditingkatkan.

Sejak berganti status dari lembaga penyiaran pemerintah menjadi lembaga penyiaran publik, RRI mengalami berbagai perubahan. Perubahan ini mengubah orientasi institusi secara prinsip, dari orientasi sebagai corong pemerintah menjadi orientasi pengabdian publik. Perubahan orientasi ini juga mengubah pola kerja serta pola pembinaan sumber daya manusia, khususnya SDM yang bertugas di bidang program siaran jurnalistik.

Sebagai Lembaga Penyiaran Publik (LPP), seluruh program siaran RRI harus berorientasi kepada pemenuhan kepentingan publik. Sebagai contoh, pada kasus rencana kenaikan bahan bakar minyak, di masa lalu, RRI dapat lebih banyak menampilkan sudut pandang pemberitaan dari rencana pemerintah kenaikan BBM. Saat ini, pemberitaan tentang rencana kenaikan bahan bakar minyak harus lebih berimbang. Pemberitaan RRI harus menampilkan berbagai reaksi kelompok-kelompok masyarakat. Pemerintah hanyalah salah satu simpul yang harus diliput. Selain pemerintah, berbagai kelompok masyarakat lainnya seperti pengamat politik dari berbagai institusi, lembaga swadaya masyarakat, serta masyarakat biasa juga harus digali pendapatnya secara proporsional. Dengan kata lain, secara normatif, RRI bukan lagi corong pemerintah. Isi siarannya harus menjadi cermin dinamika masyarakat yang berkembang saat ini. Tugas inilah yang dirasakan berat karena ini menyangkut perubahan pola pikir (mindset).

Kepala bidang siaran RRI cabang Bandung, Sulaeman, mengakui tidak mudah mengubah paradigma tersebut. Beberapa hal menyebabkan sulitnya mengubah paradigma tersebut, mulai dari hal yang substansial hingga hal teknis. Secara substansial, tidak mudah untuk mindset kru redaksi maupun siaran untuk mengubah sudut pandang pemberitaan agar lebih berorientasi pada pemenuhan kepentingan publik. Perubahan mindset ini harus diwujudkan bukan hanya dalam jargon atau kata-kata bahwa RRI harus berubah. Perubahan mindset ini harus diwujudkan secara konkrit. Manakala seorang reporter turun ke lapangan, maka cara pandangnya terhadap realitas yang diliputnya harus menjadi apa pentingnya fakta atau peristiwa itu dilaporkan kepada pendengar. Apa yang ingin diketahui pendengar dari fakta atau peristiwa yang tengah diliput oleh reporter. Apa pertanyaan yang ingin diajukan oleh pendengar.

Bukan program apa yang ingin disosialisasikan oleh seorang pejabat pemerintah kepada masyarakat.

Perubahan mindset ini secara substansial juga harus mengubah pola kerja reporter lapangan dari sekedar mengekor aktivitas pejabat untuk dapat dilaporkan, menjadi lebih banyak terjun ke berbagai simpul masyarakat.

Sebagai contoh, pada kasus rencana kenaikan BBM, dahulu, seorang reporter cukup menghubungi seorang pejabat berwenang, menanyakan mengapa harga BBM harus dinaikan, serta kapan kenaikan itu akan dilakukan. Sekarang, seorang reporter tetap harus menghubungi pejabat berwenang tersebut. Namun selain itu ia (bersama tim kerjanya) harus juga menghubungi para pengamat, LSM-LSM yang mengamati masalah BBM, dan berbagai kelompok masyarakat seperti misalnya pedagang di pasar tradisional, para pengemudi angkutan kota, ibu rumah tangga biasa, serta berbagai kelompok masyarakat lainnya. Contoh kasus ini menyebabkan pekerjaan tim redaksi menjadi lebih banyak, namun sesungguhnya jika mampu dilaksanakan akan mampu menghasilkan karya jurnalistik yang lebih berkualitas.

Perubahan mindset juga tidak hanya tercer- 
Tabel 1 Kriteria Kandidat SDM Bidang Jurnalistik Saat Direkrut

\begin{tabular}{|c|c|c|c|}
\hline & RRI & Lita FM & PR FM \\
\hline Pendidikan & Minimal D3 & Minimal D3 & Minimal D3 \\
\hline Bidang pendidikan & Bebas & Bebas & Bebas \\
\hline $\begin{array}{l}\text { Latar belakang pendidikan } \\
\text { tambahan jurnalistik } \\
\text { sebelum rekruitmen }\end{array}$ & $\begin{array}{l}\text { Tidak wajib tetapi menjadi nilai } \\
\text { tambah }\end{array}$ & Tidak wajib & $\begin{array}{l}\text { Tidak wajib tetapi menjadi nilai } \\
\text { tambah }\end{array}$ \\
\hline $\begin{array}{l}\text { Pengalaman bekerja di } \\
\text { bidang jurnalistik }\end{array}$ & $\begin{array}{l}\text { - Tidak wajib tetapi menjadi } \\
\text { nilai tambah }\end{array}$ & $\begin{array}{l}\text { - Tidak wajib tetapi } \\
\text { menjadi nilai tambah }\end{array}$ & $\begin{array}{l}\text { - Tidak wajib tetapi menjadi } \\
\text { nilai tambah }\end{array}$ \\
\hline Pengetahuan umum & $\begin{array}{l}\text { Memiliki pengetahuan umum } \\
\text { yang baik }\end{array}$ & $\begin{array}{l}\text { Memiliki pengetahuan } \\
\text { umum yang baik }\end{array}$ & $\begin{array}{l}\text { Memiliki pengetahuan umum } \\
\text { yang baik }\end{array}$ \\
\hline Wawasan jurnalistik & $\begin{array}{l}\text { Mengetahui isu aktual yang } \\
\text { bernilai berita. }\end{array}$ & $\begin{array}{l}\text { Tidak mutlak. Dibina } \\
\text { setelah ditempatkan di } \\
\text { bidang jurnalistik }\end{array}$ & $\begin{array}{l}\text { Mengetahui isu aktual yang } \\
\text { bernilai berita. } \\
\text { Memiliki pengetahuan yang } \\
\text { cukup mendalam tentang isu } \\
\text { aktual yang bernilai berita }\end{array}$ \\
\hline $\begin{array}{l}\text { Pemahaman etika profesi \& } \\
\text { peraturan perundang- } \\
\text { undangan yg relevan }\end{array}$ & Harus memahami secara mandiri & $\begin{array}{l}\text { Memahami dengan } \\
\text { pendampingan senior }\end{array}$ & Harus memahami secara mandiri \\
\hline \multicolumn{4}{|c|}{$\begin{array}{l}\text { Keterampilan jurnalistik : } \\
\end{array}$} \\
\hline $\begin{array}{l}\text { Keterampilan perencanaan, } \\
\text { pemilihan isu bernilai berita }\end{array}$ & $\begin{array}{l}\text { Cukup mengetahui isu aktual. } \\
\text { Perencanaan liputan dibimbing } \\
\text { oleh senior/atasan. }\end{array}$ & $\begin{array}{l}\text { Diarahkan/dibimbing oleh } \\
\text { senior/atasan. }\end{array}$ & $\begin{array}{l}\text { Cukup mengetahui isu aktual. } \\
\text { Perencanaan liputan dibimbing } \\
\text { oleh senior/atasan. }\end{array}$ \\
\hline $\begin{array}{l}\text { Keterampilan } \\
\text { informasi : }\end{array}$ & $\begin{array}{l}\text { Mampu melakukan paper trail, } \\
\text { people trail, elektronik trail }\end{array}$ & $\begin{array}{l}\text { Dibimbing secara bertahap } \\
\text { oleh senior/atasan }\end{array}$ & $\begin{array}{l}\text { Mampu melakukan paper trail, } \\
\text { people trail, elektronik trail }\end{array}$ \\
\hline
\end{tabular}

people trail, elektronik trail.
Keterampilan mengolah informasi sesuai format media.

Mampu menulis secara logis. Kemampuan menulis untuk format radio dibina secara bertahap.

Kemampuan mengedit pesan suara (sound bite) dibina secara bertahap.

Kemampuan menghasilkan produk jurnalistik dibina secara bertahap.

Kemampuan reportase lapangan

(Radio on the spot Reportase)

dibina secara bertahap.

\section{Keterampilan presentasi}

Memiliki artikulasi suara yang jelas.

Kemampuan bertutur yang baik, berbicara secara runtut dan logis

Di RRI Tahap awal kompetensi dibidang presentasi untuk jurnalis adalah mampu melakukan reportase langsung. Kemampuan presentasi sebagai penyiar dilakukan dari jalur yang berbeda, dibina khusus dari SDM penyiar, bukan reporter. Dibimbing secara bertahap agar mampu melakukan reportase langsung
Tidak wajib. Dibina secara bertahap setelah direkrut.
Dibina secara bertahap agar mampu :

Menulis dengan baik.

Menulis dalam bahasa tutur untuk format radio siaran.

Mengedit pesan suara.

Menghasilkan karya/produk jurnalistik.

Melakukan (Radio on the spot Reportase)

Dibimbing secara bertahap agar mampu melakukan reportase siaran langsung maupun rekaman. Reportase dilakukan dengan konsep ROSR maupun bincangbincang dengan penyiar di studio.

Reporter bisa saja

merangkap penyiar.

Tidak wajib. Dibina secara bertahap setelah direkrut.
Mampu menulis secara logis. Kemampuan menulis untuk format radio dibina secara bertahap.

Kemampuan mengedit pesan suara (sound bite) dibina secara bertahap.

Kemampuan menghasilkan produk jurnalistik dibina secara bertahap.

Kemampuan reportase lapangan (Radio on the spot Reportase) dibina secara bertahap.

Dibimbing secara bertahap agar mampu melakukan reportase langsung.
Kemampuan analisis

Mampu menganalisis isu bernilai berita yang tidak terlalu rumit.

Kemampuan untuk menganalisis kompleksitas isu dibina secara bertahap.

\begin{tabular}{llll}
\hline & \multicolumn{2}{c}{ Karakter } \\
\hline Karakter/kepribadian & Memiliki minat dan semangat & Memiliki minat dan & Tangguh, memiliki etos kerja \\
& menjalani profesi jurnalis. & semangat menjalani profesi & yang baik. \\
& Memiliki etos kerja yang baik & jurnalis.
\end{tabular}
semangat menjalani profesi yang baik
Memiliki kesad profesi baik risiko negatif maupun positif.

Sumber: Yudhapramesti dan Fadilah, 2012 
min dalam program siaran reportase, namun juga seluruh program siaran. Dalam acara talkshow misalnya, RRI harus menyiarkan topiktopik siaran talkshow yang lebih berorientasi kepada kepentingan publik. Kalaupun ada acara siaran talkshow yang jam siarnya dibeli oleh instansi pemerintah untuk sosialisasi program pemerintah, RRI harus tetap memperhatikan keseimbangan nara sumber serta bobot pertanyaan agar tetap kritis, skeptis, serta berada dalam sudut pandang kepentingan publik, bukan sekedar corong pemerintah.

Pada tataran ideal, perubahan mindset ini juga membawa konsekuensi perubahan teknis pola kerja tim redaksi dan program siaran jurnalistik. Jika sebelumnya reporter cukup "ngepos" di satu instansi pemerintah untuk menunggu informasi, maka jika memang ingin berorientasi kepada kepentingan publik, reporter RRI harus lebih rajin menjelajah ke "kantong-kantong" masyarakat untuk memperoleh berita, meski tentu saja tidak pantang untuk tetap mendatangi kantor instansi pemerintah jika memang diperlukan.

Perubahan pola pikir dan pola kerja ini menuntut kualifikasi jurnalis lebih tinggi dari sebelumnya. Sebelum dan sesudah perubahan orientasi dari lembaga penyiaran pemerintah menjadi lembaga penyiaran publik, tugas jurnalis radio secara teknis nampak sama saja, yaitu menggali informasi, mengolahnya menjadi pesan dalam bentuk suara, kemudian mempresentasikannya. Namun perubahan orientasi menjadi lembaga penyiaran publik menuntut jurnalis RRI jurnalis harus memiliki pengetahuan umum yang tinggi, paham akan isu aktual yang tengah berkembang di masyarakat, bukan sekedar isu yang sedang ramai dibicarakan, namun isu yang benar-benar penting bagi hajat hidup orang banyak. Selain terampil menggali informasi dari berbagai sumber seperti paper trail, people trail, serta elektronik trail, jurnalis RRI juga harus mampu melakukan riset untuk kepentingan pemberitaan atau produksi karya jurnalistik. Sejalan dengan perkembangan teknologi, RRI juga telah beradaptasi dengan teknologi yang lebih baru, yaitu media berbasis internet. Karena RRI juga telah memiliki media online, maka jurnalisnya juga harus mampu mengolah informasi untuk mengisi media online. Dengan kata lain jurnalis RRI juga harus memiliki kemampuan teknis mengolah pesan untuk berbagai media, yaitu pesan suara untuk siaran terrestrial, serta pesan teks, gambar/foto, dan video untuk media online. Terakhir, jurnalis RRI juga harus memiliki kemampuan evaluasi atas kasus yang tengah ia liput.

Sayangnya, seperti diakui oleh Sulaeman, tidak mudah bagi RRI untuk memperoleh jurnalis dengan kualifikasi tersebut. Saat ini, sebagian besar kru yang bekerja pada bagian program siaran serta redaksi di RRI adalah awak siar yang telah senior. Meski mengaku telah mencoba mengubah mindset, di tangan para senior, masih banyak produk siaran jurnalistik RRI yang digarap dengan sudut pandang lama. Nara sumber dari kalangan pemerintah masih mendominasi berita RRI. Berita masih sering digarap dalam sudut pandang aksi-aksi atau tindakan-tindakan yang dilakukan oleh para pengambil kebijakan atau dengan kata lain kurang bottom up.

Perubahan status menjadi LPP membuat status kepegawaian RRI menjadi tidak jelas. Sebelumnya, status para pegawai RRI adalah pegawai negeri sipil. Setelah berubah menjadi LPP, RRI tidak dapat leluasa merekrut pegawai baru untuk regenerasi, karena tidak ada lagi status PNS bagi karyawannya. RRI juga belum mendapat izin untuk merekrut karyawan tetap karena ketidakjelasan statusnya. RRI hanya dapat merekrut karyawan kontrak.

Kondisi ini membuat pengelolaan program siaran RRI saat ini tidak bisa dilakukan optimal. Di satu sisi tidak mudah untuk mengubah paradigma berpikir karyawan lama, di sisi lain merekrut karyawan baru juga belum memungkinkan. Namun demikian, kesadaran untuk terus membenahi program siaran jurnalistik agar lebih memihak pada publik sangatlah disadari oleh para pengambil kebijakan utama di RRI. Upaya ini terus dilakukan secara bertahap. Kesadaran ini menunjukkan bahwa jika masalah status kepegawaian telah dapat diatasi, maka akan terbuka peluang untuk para jurnalis baru bergabung di RRI. Pada saat itu diharapkan standar kompetensi untuk para jurnalis RRI dapat ditingkatkan menuju kompetensi yang dicita-citakan.

Radio Lita FM yang telah berdiri sejak tahun 1972, merupakan radio siaran swasta yang mengusung konsep radio keluarga. Sebagai radio keluarga, Radio Lita FM menyasar kha- 
layak seluruh anggota keluarga. Karenanya program siaran Radio Lita FM menyasar orang tua baik pria maupun wanita, anak-anak maupun remaja. Dalam implementasinya, program siaran Radio Lita FM terdiri dari program siaran musik dengan berbagai jenis aliran musik, siaran perbincangan hiburan, serta beberapa program siaran jurnalistik dalam bentuk talkshow, reportase, serta berita.

Konsekuensi dari konsep sebagai radio untuk keluarga adalah lebarnya kelompok khalayak yang dibidik oleh Radio Lita FM. Format radio siaran masa kini biasanya cenderung pada format yang terfokus untuk membidik kelompok khalayak yang relatif sempit. Sebagai contoh, ada radio yang hanya membidik kelompok remaja kelas sosial ekonomi menengah ke atas, atau kelompok wanita dewasa muda kelas sosial ekonomi menengah. Berbeda dari radio lain pada umumnya, Radio Lita membidik hampir seluruh kalangan masyarakat yang terjangkau oleh pancaran siarannya. Konsep ini mengakibatkan khalayak Radio Lita FM terkelompokkan sesuai acara siaran favoritnya masing-masing. Sebagai contoh, ada kelompok khalayak penyuka musik keroncong, ada pula kelompok khalayak penyuka lagu sunda, dll.

Pada sisi manajerial, Radio Lita FM merupakan radio siaran swasta yang tengah mencoba membenahi manajerialnya dari konsep manajemen keluarga menjadi manajemen yang lebih profesional. Menurut keterangan kepala bidang pemberitaan, Doni Prasetyo, jika sebelumnya manajemen lebih bersifat kekeluargaan dimana pemilik perusahaan menjadi pengambil keputusan tertinggi, kini jabatan-jabatan terpenting mulai diisi oleh SDM yang direkrut secara profesional sesuai dengan bidang keahlian yang dibutuhkan. Kini, programmer siaran Radio Lita FM tidak lagi dijabat oleh anggota keluarga, namun dijabat oleh SDM profesional yang telah memiliki pengalaman bekerja di radio siaran.

Berkaitan dengan program siaran jurnalistik, sejak delapan tahun terakhir Radio Lita FM mulai membenahi kualitas siaran jurnalistik mereka dengan membenahi organisasi kerja serta kualitas SDM di bidang jurnalistik. Sejak tahun 2005 Radio Lita memiliki reporter serta memroduksi siaran berita sendiri. Sebelumnya Radio Lita hanya ikut menyiarkan program siaran berita yang diproduksi bersama oleh Lembaga Produksi Radio Siaran Swasta Jawa Barat. Ada tiga orang kru yang ditugaskan untuk menangani program siaran jurnalistik, khususnya untuk menjadi reporter lapangan.

Jika sedang terjadi momen besar yang membutuhkan tambahan kru, maka seluruh penyiar Radio Lita FM dapat diberdayakan untuk menjadi reporter. Pada radio siaran, pola kerja rangkap tugas atau jabatan biasa dilakukan untuk menghemat sumber daya manusia. Namun seperti diakui oleh Doni, kru yang tugas utamanya menjadi penyiar, pada umumnya belum memiliki kompetensi jurnalistik yang memadai.

PR FM dikelola oleh PT Mustika Parahyangan, anak perusahaan dalam naungan Grup Pikiran Rakyat, sebuah grup penerbitan pers terbesar di Jawa Barat. Sebagai sebuah perusahaan, PT Mustika Parahyangan yang kini mengelola PR FM telah berdiri cukup lama, sejak tahun akhir tahun 1980 an. Namun radio yang dikelolanya telah beberapa kali berganti konsep format siaran, target khalayak, bahkan nama radio siaran.

Baru sejak tahun 2009, nama PR FM digunakan dengan nama resmi PRFM 107.5 NEWS CHANNEL, dengan tagline "Anda lah reporter kami". PR FM mengusung format siaran radio berita berbasis soft news, dengan basis informasi dari warga atau lebih dikenal dengan konsep citizen journalism.

Dengan konsep ini, program siaran PR FM setiap waktu menampung aspirasi warga, menjadikan masyarakat sebagai wartawan dan sumber berita yang menjadi inspirasi PR FM. Melalui konsep ini pula, seluruh materi acara siaran PR FM mengusung format jurnalistik dengan bentuk siaran utama berupa talkshow yang mengundang nara sumber, penelepon atau yang biasa disebut call in, reportase, berita, serta feature. Seluruh bentuk acara siaran ini membutuhkan kru pengelola yang memiliki wawasan serta keterampilan jurnalistik. Para awak atau kru ini mengisi posisi redaksi, penyiar, serta reporter lapangan. Redaksi bertugas menyiapkan materi informasi termasuk menyortir sms yang masuk dari pendengar serta menindaklanjuti laporan pendengar (warga) kepada nara sumber atau instansi terkait.

Konsep citizen journalism membuat produk jurnalistik PR FM berbeda dari RRI dan Lita 
FM serta radio yang mengisi konten siaran jurnalistik lainnya. Melalui konsep citizen journalism, PR FM memberi porsi untuk membuat tema materi siaran yang lebih bersifat bottom up karena berasal dari laporan warga. Seringkali tema ini sangat bernilai lokal, berbeda dari informasi arus besar yang biasanya dilahirkan dari media nasional. Konsep menuntut kemampuan pengelola untuk jeli memilih tema-tema yang melawan arus utama.

Standar Kompetensi Wartawan (SKW) yang disusun oleh Dewan Pers dan berbagai organisasi kewartawanan telah membagi kategori wartawan menjadi tiga kelompok, yakni wartawan muda, wartawan madya, serta wartawan utama. Standar kompetensi ini dimaksudkan untuk menjadi rujukan berbagai pihak yang berkepentingan, terutama institusi media massa yang mempekerjakan karyawan. SKW telah disahkan dan dipublikasikan sejak tahun 2010 lalu.

Bagi media massa, SKW dapat menjadi rujukan tentang kompetensi apa yang harus dimiliki oleh wartawannya dalam melaksanakan pekerjaannya. Jika wartawannya adalah seorang wartawan muda, maka yang bersangkutan harus memiliki kompetensi apa saja. Jika wartawannya adalah wartawan madya, maka kompetensinya akan harus lebih tinggi dari wartawan muda, dan seterusnya. Standar ini akan berguna untuk berbagai kebutuhan, antara lain, untuk rekruitmen, media massa dapat mencari wartawan pada level kompetensi tertentu sesuai dengan level kompetensi yang media tersebut butuhkan. Manfaat lainnya adalah untuk penugasan, media massa dapat menugaskan wartawan pada level kompetensi tertentu sesuai bobot atau berat ringannya penugasan.

Selain media massa, ada berbagai pihak yang juga membutuhkan SKW sebagai rujukan, antara lain perguruan tinggi yang memiliki program studi pendidikan kewartawanan, terutama pada prodi yang telah melaksanakan kurikulum berbasis kompetensi. SKW dapat menjadi acuan kurikulum dimana pembelajaran di program studi kewartawanan diarahkan untuk memiliki kompetensi sesuai rujukan SKW, minimal untuk mencapai kompetensi yang paling rendah.

Hingga kini, SKW masih dalam tahap sosialisasi. Satu persatu media massa besar mulai mengirimkan karyawannya untuk mengikuti uji kompetensi. Namun demikian, pada ketiga radio siaran yang diteliti, belum satu pun radio siaran yang mewajibkan jurnalisnya untuk mengikuti uji kompetensi. Baik RRI, PR FM, maupun Lita FM, masih lebih mengandalkan standar yang ditetapkan oleh institusi mereka secara internal. Namun meski belum mewajibkan, beberapa jurnalis radio sudah diikutsertakan untuk mengikuti uji kompetensi wartawan.

Berdasarkan penelusuran di lapangan, dapat dirumuskan bahwa terdapat kesenjangan antara kondisi yang terjadi dan kondisi ideal yang diharapkan. Pengelola RRI, PR FM, serta Lita FM menyadari jika hingga saat ini kualitas reporter yang mereka miliki belum merata. Kondisi ini terjadi karena saat rekruitmen mereka tidak dapat menetapkan standar kompetensi calon jurnalis yang terlalu spesifik sesuai dengan kebutuhan institusi mereka masing-masing. Standar kompetensi tidak bisa terlalu ketat ditetapkan karena tidak mudah memperoleh calon kandidat yang memenuhi kebutuhan radio siaran.

Selain masalah rekruitmen yang diakui sendiri oleh para pengelola, peneliti juga menemukan fakta bahwa masih banyak produk jurnalistik pada ketiga radio siaran yang diamati, yang belum optimal kualitasnya. Kelemahan biasanya terjadi pada aspek pemahaman terhadap filosofi jurnalistik, kemandirian dalam memilih dan menentukan isu pemberitaan, dan kemampuan untuk mengolah pesan suara, terutama dalam materi penulisan untuk siaran radio.

Pengelola radio siaran telah memahami tugas utama media sebagai penyampai pesan. Namun pada praktiknya, pesan yang disampaikan masih lebih banyak bersifat top down, penyampai pesan dari atas ke bawah, dari pemerintah ke masyarakat luas, dari kalangan elit ke kalangan bawah, dari orang-orang terkenal ke orangorang biasa, dibandingkan sebaliknya, pesan yang bersifat bottom up.

Terdapat berbagai alasan yang melatari pesan yang lebih banyak bersifat top down tersebut. Alasan pertama adalah kemudahan untuk menjangkau sumber berita. Wartawan lebih mudah menghubungi pejabat pemerintah dibandingkan dengan turun ke pemukiman warga untuk menelusuri peristiwa yang bernilai berita. Alasan lainnya adalah karena ketidaktahuan wartawan untuk menelusuri berita langsung ke 
masyarakat luas, keterbatasan sumber daya dan waktu sehingga lebih praktis menghubungi nara sumber pejabat pemerintah, hingga kemalasan wartawan untuk blusukan.

Radio siaran sering kurang mandiri dalam memilih isu yang dapat dijadikan karya jurnalistik. Memilih dan menentukan isu yang penting serta menarik bagi khalayak bukanlah hal mudah. Apalagi jika isu tersebut berlawanan dengan isu yang tengah ramai dibicarakan. Seringkali pengelola memutuskan untuk mengikuti isu yang tengah ramai dibahas di berbagai media, karena takut gagal menarik perhatian khalayak jika menentukan isu sendiri, atau justru karena pengelola juga terpengaruh oleh isu yang diagendakan oleh media lain yang lebih besar. Shoemaker dan Reese (dalam Severin, 2005) menyebutkan bahwa kadang kala media elit juga ikut menjadi salah satu faktor yang ikut menentukan isi media. Praktik ini dinamakan penentuan agenda intermedia (intermedia agenda setting). Padahal tugas utama jurnalis juga adalahmengangkat suara minoritas, peristiwa penting yang mungkin tersembunyi. Dari ketiga radio yang diamati, PR FM lah yang dapat dikatakan paling memiliki kemandirian untuk memilih serta menentukan isu. Ini terjadi karena PR FM memberikan kesempatan pada pendengarnya untuk membiasakan melaporkan berbagai peristiwa penting.

Pada ketiga radio siaran yang diamati, sebagian besar format penulisannya masih terpengaruh oleh format penulisan untuk media cetak. Kondisi ini juga diamini oleh ketiga pengelola radio siaran yang diteliti. Ketiganya mengaku sulit untuk mengubah kebiasaan serta pemahaman jurnalis mengenai formula penulisan bahasa radio. Selain format penulisan, kemampuan mengedit/ menyunting suara juga masih belum optimal. Hasil suntingan suara masih banyak yang belum terdengar natural. Tidak banyak jurnalis radio yang mampu merencanakan elemen suara yang hendak ia ambil di lapangan agar mudah saat proses penyuntingan. Akibatnya, banyak jurnalis terutama jurnalis muda yang kebingungan untuk menyunting suara karena terlalu banyak sumber suara yang ia rekam saat ke lapangan.

Selain tiga hal tersebut, tantangan yang telah dan akan terus berkembang di masa yang akan datang adalah bahwa jurnalis radio juga harus mampu beradaptasi dengan perkembangan teknologi media baru yaitu internet. RRI, Radio Lita FM, serta PR FM telah memiliki website dan melakukan streamingon air, serta memiliki halaman khusus untuk menyampaikan produk jurnalistik, meski belum seintensif radio siaran terestrialnya. Hingga saat ini website yang juga mengelola media online pada ketiga radio siaran tersebut masih bersifat sebagai media penunjang untuk mendekati khalayak pengguna internet. Namun seiring berjalannya waktu, media online diramalkan akan menjadi media utama. Kondisi ini mengisyaratkan bahwa jurnalis radio juga harus mampu bekerja dalam pola kerja media konvergensi. Pada pola kerja ini jurnalis radio harus mampu menghasilkan karya untuk radio siaran serta karya untuk media online. Di dalam media berbasis internet, kemampuan memproduksi karya bukan hanya berupa tulisan atau foto, melainkan juga karya audio. Dengan demikian, kemampuan untuk mengolah pesan suara pun perlu tetap dijaga.

\section{SIMPULAN}

Berdasarkan temuan penelitian, dapat diambil simpulan bahwa seorang jurnalis radio harus memahami fungsi dan perannya sebagai pembawa pesan yang tidak hanya top down namun juga bottom up. Jurnalis harus mampu menyuarakan pesan-pesan penting yang mungkin tersembunyi. Jurnalis radio harus memahami karakter radio siaran, mengerti cara mengedepankan keunggulan radio siaran dan menutupi kelemahannya, mampu mengolah pesan suara sehingga menarik dan mudah dimengerti. Jurnalis radio harus beretika dalam menjalankan aktivitasnya. Menghadapi perkembangan teknologi yang berbasis internet, jurnalis radio juga harus mampu bekerja dalam pola kerja media konvergensi.

Terdapat kesenjangan antara kondisi nyata dan kondisi ideal jurnalis radio yang mengelola acara siaran jurnalistik. Pengelola radio siaran menyadari bahwa kualitas jurnalis radio belum merata. Tidak mudah mendidik jurnalis radio agar memiliki kualifikasi yang terstandarisasi. Kurang maksimalnya kualitas SDM membuat radio siaran sulit untuk menghasilkan karya jurnalistik yang berkualitas. Kondisi ini menjadi isyarat bagi perguruan tinggi yang meng- 
hasilkan calon-calon jurnalis radio agar dapat menyediakan calon-calonpengisi posisi jurnalis radio yang berkualitas.

\section{DAFTAR PUSTAKA}

Bogdan, R. C. \& Sari, K. B. (1982). Qualitative research for education: an inttroduction to theory and methods. Boston: Allyn and Bacon, Inc.

Dewan Pers. (2010). Peraturan dewan pers nomor 1/Peraturan-DP/II/2010 tentang STANDAR KOMPETENSI WARTAWAN.

Fadilah, E. (2007). Pemanfaatan model assure untuk meningkatkan keterlibatan aktif mahasiswa dalam pembelajaran teknik reportase. Tesis. Sekolah Pascasarjana UPI, Bandung.

Gibson, R. (1991). Radio and television reporting. USA: Allyn and Bacon.

Hanitzsch, T. (2001). Rethinking journalism education in indonesia: nine theses. Jurnal
Mediator Universitas Islam Bandung, Vol. 2. Jonathans, E. (2006). Socrates di radio, esai-esai jagad keradioan. Surabaya: Gong Plus, Suara Surabaya FM 100.

Kriyantono, R. (2010). Teknis praktis riset komunikasi. Jakarta: Kencana.

Moleong, J. L. (2006). Metodologi penelitian kualitatif. Bandung: PT. Remaja Rosdakarya.

Romli, A. S.(2005). Jurnalistik praktis untuk pemula. Bandung: PT Remaja Rosda Karya.

Sasono, E. (2005). Jurnal pantau, ed. 4.

Severin, W. J. \& Tankard, J. W. Jr. (2005). Teori komunikasi, sejarah, metode, dan terapan di media massa. Jakarta: Kencana.

Yudhapramesti, P. (2009). Peran radio siaran sebagai media lokal dalam pembangunan daerah. Tesis. Sekolah Arsitektur Perencanaan dan Pengembangan Kebijakan ITB, Bandung. 